\title{
Differential effects of single fatty acids and fatty acid mixtures on the phosphoinositide 3-kinase/Akt/eNOS pathway in endothelial cells
}

\author{
Kim G. Jackson ${ }^{1,2} \oplus$. Katie J. Newens ${ }^{1} \cdot$ Michael J. Fry ${ }^{2,3} \cdot$ Abby K. Thompson ${ }^{1} \cdot$ Christine M. Williams $^{1,2}$
}

Received: 1 October 2021 / Accepted: 25 January 2022 / Published online: 14 February 2022

(c) The Author(s) 2022

\begin{abstract}
Scope Dietary fat composition is an important modulator of vascular function. Non-esterified fatty acids (NEFA) enriched in saturated fatty acids (SFA) are thought to reduce vascular reactivity by attenuating insulin signalling via vasodilator pathways (phosphoinositide 3-kinase (PI3K)/Akt/endothelial nitric oxide synthase (eNOS)) and enhancing signalling via pro-inflammatory pathways.

Methods To examine the effects of fatty acids on these pathways, human aortic endothelial cells were incubated with single fatty acids, and mixtures of these fatty acids to mimic typical NEFA composition and concentrations achieved in our previous human study. RNA was extracted to determine gene expression using real-time RT-PCR and cell lysates prepared to assess protein phosphorylation by Western blotting.

Results Oleic acid $(\mathrm{OA}, 100 \mu \mathrm{M})$ was shown to down regulate expression of the insulin receptor, PTEN and a PI3K catalytic

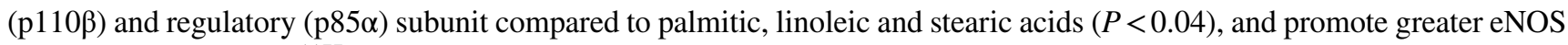
phosphorylation at $\operatorname{Ser}^{1177}$. Both concentration and composition of the SFA and SFA plus n-3 polyunsaturated fatty acids (PUFA) mixtures had significant effects on genes involved in the PI3K/Akt pathway. Greater up-regulation was found with 800 than $400 \mu \mathrm{M}$ concentration (respective of concentrations in insulin resistant and normal individuals), whereas greater down-regulation was evident with SFA plus n-3 PUFA than SFA mixture alone.

Conclusion Our findings provide novel insights into the modulation of the PI3K/Akt/eNOS pathway by single fatty acids and fatty acid mixtures. In particular, OA appears to promote signalling via this pathway, with further work required to determine the primary molecular site(s) of action.
\end{abstract}

Keywords Aortic endothelial cells · eNOS phosphorylation · Dietary fatty acids · Non-esterified fatty acids · Oleic acid · Real time RT-PCR

\begin{tabular}{|c|c|c|c|}
\hline \multicolumn{2}{|c|}{ Abbreviations } & eNOS & Endothelial nitric oxide synthase \\
\hline \multirow[t]{2}{*}{ Akt2 } & V-akt murine thymoma viral oncogene homo- & EPA & Eicosapentaenoic acid \\
\hline & logue 2 & FBS & Foetal bovine serum \\
\hline BSA & Bovine serum albumin & GCPR & G coupled protein receptor \\
\hline \multicolumn{2}{|c|}{ DHA } & HAEC & Human aortic endothelial cells \\
\hline & & IKK $\beta$ & Inhibitor- $\kappa \beta$ kinase $-\beta$ \\
\hline & & IR & Insulin receptor \\
\hline \multirow[t]{2}{*}{$\triangle$} & Kim G. Jackson & IRS-1 & Insulin receptor substrate- 1 \\
\hline & k.g.jackson@ @reading.ac.uk & LA & Linoleic acid \\
\hline \multirow{3}{*}{1} & & $\mathrm{LC}$ & Long chain \\
\hline & $\begin{array}{l}\text { Hugh Sinclair Unit of Human Nutrition, Department of Food } \\
\text { and Nutritional Sciences, University of Reading, Harry }\end{array}$ & LVM & Large vessel medium \\
\hline & Nursten Building, Reading RG6 6DZ, UK & MAPK & Mitogen-activated protein kinase \\
\hline \multirow[t]{2}{*}{2} & Institute for Cardiovascular and Metabolic Resea & MUFA & Monounsaturated fatty acids \\
\hline & University of Reading, Reading RG6 6AS, UK & NEFA & Non-esterified fatty acids \\
\hline \multirow[t]{2}{*}{3} & School of Biological Sciences, University of & NFKB & Nuclear factor kappa-B \\
\hline & Hopkins Building, Reading RG6 6UB, UK & $\mathrm{OA}$ & Oleic acid \\
\hline
\end{tabular}




$\begin{array}{ll}\text { PA } & \text { Palmitic acid } \\ \text { PI3K } & \text { Phosphoinositide 3-kinase } \\ \text { PTEN } & \text { Phosphatase and tensin homolog } \\ \text { PUFA } & \text { Polyunsaturated fatty acids } \\ \text { SA } & \text { Stearic acid } \\ \text { SFA } & \text { Saturated fatty acids } \\ \text { VCAM } & \text { Vascular cell adhesion molecule }\end{array}$

\section{Introduction}

Elevated levels of non-esterified fatty acids (NEFA), characteristic of insulin resistant states such as obesity and type II diabetes, have been proposed to mediate their effects on vascular function by modulating insulin signalling pathways in the endothelium. In support of this, Lind et al. [1] reported the impairment in forearm blood flow during NEFA elevation to be reversed by insulin infusion in healthy subjects. In a study performed in rats, biopsies taken from the aorta showed evidence of NEFA-induced impairment of the phosphoinositide 3-kinase (PI3K) pathway, with a significant reduction in the phosphorylation of insulin receptor substrate-1 (IRS-1), Akt and endothelial nitric oxide synthase (eNOS), together with impaired responses to the endothelial-dependent vasodilator, acetylcholine [2]. Both studies achieved NEFA elevation using a commercially available triacylglycerol infusion, Intralipid, which is rich in n-6 polyunsaturated fatty acids (PUFA). Our previous human study found the experimental elevation of NEFA after feeding a test oil containing saturated fatty acids (SFA) with long chain (LC) n-3 PUFA to reverse the impairment in flow-mediated dilatation observed with SFA alone [3], confirming previous suggestions that dietary fat composition may be an important modulator of vascular function. Studies in endothelial cells examining the impact of dietary fat composition have reported more detrimental effects of SFA (palmitic acid (PA)) than MUFA (oleic acid (OA)) and n-6 PUFA (linoleic acid (LA)) on the phosphorylation status of the PI3K pathway and nitric oxide production [4-7] following insulin stimulation. In visceral adipocytes, OA has been shown to protect against insulin resistance by regulating the expression of genes in the PI3K signalling pathway [8], suggesting that a similar mechanism may also operate in the endothelium.

The mitogen-activated protein kinase (MAPK) pathway, which leads to the enhanced expression of the vasoconstrictor endothelin- 1 and cell adhesion molecules, has also been shown to be activated following insulin binding to endothelial cells. Although dietary fat composition has been reported to have an impact on inflammatory gene expression in endothelial cells [7, 9-12], there is considerable disparity in the findings in the literature. A study performed by our group using human umbilical vein endothelial cells has shown PA, OA and LA to up-regulate cell adhesion molecule expression, whereas docosahexaenoic acid (DHA) tended to down-regulate expression [11]. In vitro studies have indicated that fatty acids may mediate some of their effects on cell adhesion molecule expression by activating inhibitor- $\kappa \beta$ kinase- $\beta$ (IKK $\beta$ ), a serine kinase that regulates the pro-inflammatory transcription factor nuclear factor kappa-B (NFKB) [4, 12], but which also uses IRS-1 as a substrate for serine phosphorylation [13, 14]. Fatty acids were shown to induce IKK $\beta$ activity in a dose dependent manner, with PA showing greater activation than OA and LA, attenuating insulin-mediated eNOS phosphorylation and reducing nitric oxide production [4]. IKK $\beta$ may therefore provide a common molecular locus through which fatty acids mediate their effects on inflammation and vascular function.

Many of cell studies conducted to date have been performed using a select range of fatty acids which have been tested individually. This limits their extrapolation to the normal physiological state wherein the composition of NEFA comprises a mixture of fatty acids reflecting diet and adipose tissues compositions. The present in vitro study of human aortic endothelial cells (HAEC) had two aims; (1) to determine the impact of single fatty acids on the gene expression of key proteins involved in insulin signalling in endothelial cells, and, (2) to use mixtures of fatty acids which mimic plasma NEFA compositions and concentrations achieved in our human study (Clinicaltrials.gov NCT01351324) which compared acute effects of test oils rich in SFA and SFA with LC n-3 PUFA on vascular reactivity [3]. The findings provide novel insights into the regulation of the PI3K dependent pathway by OA in endothelial cells, with down-regulation of the gene expression of the PI3K subunits ( $110 \beta$ and $\mathrm{p} 85 \alpha$ ) and phosphatase and tensin homolog (PTEN) associated with greater eNOS phosphorylation at Ser ${ }^{1177}$. In addition, our findings also contribute to our understanding how the concentration and composition of fatty acid mixtures modulate the PI3K/Akt pathway in the endothelium.

\section{Materials and methods}

\section{Cell culture}

Clonetics $^{\mathrm{TM}}$ single donor HAEC (Lot no. 5F1352.1, Lonza Biologics Plc, Slough, UK) were maintained in complete medium; endothelial basal medium-2 with SingleQuot ${ }^{\mathrm{TM}}$ supplement and growth factors [hydrocortisone, human fibroblast growth factor-B, vascular endothelial growth factor, insulin-like growth factor-1, human epidermal growth factor, gentamicin sulphate amphotericin B-1000, heparin, ascorbic acid and 2\% (v/v) foetal bovine serum (FBS)]. Only endothelial cells passaged less than four times were used for experiments. 
To examine the acute and chronic effects of single fatty acids on the mRNA expression of genes involved in the insulin signalling pathway and vascular function, endothelial cells were incubated for 3 and $24 \mathrm{~h}$ in the presence of the fatty acid-BSA complexes. Fatty acid mixtures were only incubated with cells for $3 \mathrm{~h}$ to mimic the design of our human study. For the $3 \mathrm{~h}$ (acute) incubations, cells were grown to $80 \%$ confluence in six-well plates and then incubated in large vessel endothelial cell basal medium (LVM; TCS CellWorks, Buckingham, UK) containing $2 \%(\mathrm{v} / \mathrm{v})$ FBS and minimal growth factor supplements (heparin, hydrocortisone, human epidermal growth factor and fibroblast growth factor) for $21 \mathrm{~h}$. The cells were then washed with HEPES buffered saline solution before incubation with serum-free LVM containing the fatty acid treatments for $3 \mathrm{~h}$. For the $24 \mathrm{~h}$ (chronic) incubations, the treatments were included in both the $21 \mathrm{~h}$ incubation with LVM containing $2 \%(\mathrm{v} / \mathrm{v})$ FBS and the $3 \mathrm{~h}$ incubation with serum-free LVM. Since these cell experiments were also used to determine the effects of the fatty acid incubations on the phosphorylation status of selected proteins in the insulin signalling pathways, cells were incubated with Krebs-Ringer-HEPES buffer [15] for $1 \mathrm{~h}$ before RNA extraction or insulin stimulation.

\section{Fatty acid treatments}

Sodium salts of PA, OA, LA, SA, eicosapentaenoic acid (EPA) and DHA (Sigma) were used to prepare stock solutions of the fatty acid-BSA complexes (molar ratio of 2.5:1) as previously described [11]. The fatty acid-BSA stock solutions were filter sterilised before the concentration of the fatty acids within the stock solutions were verified following extraction of the lipids and separation of the fatty acid methyl esters using gas chromatography [16]. The fatty acid-BSA stock solutions were then stored in aliquots at $-20{ }^{\circ} \mathrm{C}$ until dilution to the appropriate concentration in the LVM. Cells were treated with physiological concentrations $(100 \mu \mathrm{M})$ of the single fatty acids PA, OA, LA and SA, with a lower concentration $(10 \mu \mathrm{M})$ for the LC n-3 PUFA, EPA and DHA. Mixtures of fatty acid representative of the peak postprandial plasma NEFA profiles reached during the acute human study [3] were prepared for: (1) the SFA challenge (\% weight of total fatty acids, $39 \%$ PA, $10.7 \%$ SA, $36.8 \%$ OA, $12.0 \%$ LA, $0.2 \%$ EPA and $1.2 \%$ DHA) and (2) the SFA with LC n-3 PUFA challenge (37.1\% PA, $10.1 \%$ SA, $33.9 \%$ OA, $11.7 \%$ LA, $0.9 \%$ EPA and $6.2 \%$ DHA). The total NEFA concentrations chosen for study were $400 \mu \mathrm{M}$ and $800 \mu \mathrm{M}$ to reflect the circulating postprandial NEFA concentrations reported in healthy and insulin-resistant individuals, respectively $[17,18]$.

\section{Real time RT-PCR}

Total RNA was extracted from the cells using Qiagen RNeasy Mini Kit and QIAshredder (Qiagen Ltd., Crawley, UK) using protocols recommended by the manufacturer. cDNA was generated from 0.5 to $1.5 \mu \mathrm{g}$ samples of total RNA at $42{ }^{\circ} \mathrm{C}$ for $50 \mathrm{~min}$ (reaction volume $20 \mu \mathrm{l}$ ) using oligo $\mathrm{dT}_{12-18}$ primer (Invitrogen Ltd, Paisley, UK) and reverse transcriptase (Superscript II; Invitrogen Ltd) using protocols recommended by the manufacturer.

Specific primers for PTEN, IKK $\beta$, Akt2, PI3K catalytic (p110 $\alpha$ and $\beta$ ) and regulatory (p85 $\alpha$ and $\beta$ ) subunits were designed (Table 1) and real time RT-PCR performed as previously described [19]. The primer sequences for eNOS was obtained from Miyomoto et al. [20] and vascular cell adhesion molecule-1 (VCAM-1) from Shaw et al. [11]. The expression of each target gene was normalized to the $\beta$-actin expression and the data represent the fold change in mRNA expression relative to the BSA control (HAEC incubated with BSA equivalent to the amount present in the fatty acidBSA complexes), which is arbitrarily defined as 1 .

\section{Cell studies to determine the effects of the fatty acid treatments on insulin signalling}

To determine whether changes in gene expression could have an impact on the phosphorylation status of key proteins in the PI3K (eNOS Ser ${ }^{1177}$ and $\mathrm{Akt}^{473}$ ) and MAPK (p44/p42 at $\mathrm{Thr}^{202} / \mathrm{Thr}^{204}$ ) pathways, cells were also stimulated with $1 \mu \mathrm{M}$ of insulin (Novo Nordisk, Denmark) or HBSS for 15 min after incubation with the single fatty acids (PA, OA, LA, SA, EPA and DHA) and fatty acid mixtures (SFA and SFA with LC n-3 PUFA). This concentration of insulin was chosen based on a previous study determining insulin signalling in HAEC [15]. Cells were then placed on ice and incubated with $200 \mu \mathrm{l}$ of $1 \mathrm{X}$ lysis buffer $(20 \mathrm{mM}$ Tris- $\mathrm{HCl}$ (pH 7.5), $150 \mathrm{mM} \mathrm{NaCl}, 1 \mathrm{mM} \mathrm{Na} 2$ EDTA, $1 \mathrm{mM}$ EGTA, $1 \%$ Triton, $2.5 \mathrm{mM}$ sodium pyrophosphate, $1 \mathrm{mM}$ $\beta$-glycerophosphate, $1 \mathrm{mM} \mathrm{Na}_{3} \mathrm{VO}_{4}$ and $1 \mu \mathrm{g} / \mathrm{ml}$ leupeptin) (New England Biolabs, Hitchin, UK) supplemented with $1 \mathrm{mM}$ PMSF for $5 \mathrm{~min}$ before being scraped from the dishes.

Immunoblotting was performed as previously described [21]. Briefly, samples (30 $\mu \mathrm{g}$ protein) were run on $7.5 \%$ SDS-polyacrylamide gels and proteins transferred to nitrocellulose membranes (Hybond-ECL; Amersham, Buckinghamshire, UK) by semi-dry electroblotting $(1.5 \mathrm{~mA} /$ $\mathrm{cm}^{2}$ ). Blots were incubated with primary antibodies for antiphospho-eNOS ( $\operatorname{Ser}^{1177}$, 1:1000 dilution), anti-phospho-Akt $\left(\mathrm{Ser}^{473}, 1: 1000\right)$ or anti-phospho-MAPK 44/42 $\left(\mathrm{Thr}^{202} / \mathrm{Thr}^{204}\right.$, $1: 10,000)$ and anti-eNOS $(1: 1000)$, anti-Akt (1:1000) or antiMAPK 42/44 (1:10,000 dilution)(New England Biolabs) in Tris-Tween Buffered Saline (TTBS) containing 5\% (w/v) BSA overnight at $4^{\circ} \mathrm{C}$ on a three-dimensional rocking table. 
Table 1 Primer sequences of genes for the relative quantification of mRNAs by real-time RT-PCR

\begin{tabular}{|c|c|c|c|}
\hline Gene & Accession number & $\begin{array}{l}\text { Sequence of the forward and reverse primers } \\
\left(5^{\prime}-3^{\prime}\right)\end{array}$ & $\begin{array}{l}\text { Product } \\
\text { size (bp) }\end{array}$ \\
\hline Akt2 & BC120995 & $\begin{array}{l}\text { CATGAAGATCCTGCGGAAGG } \\
\text { GAAGGCATACTTCAGCGCAGTG }\end{array}$ & 121 \\
\hline IKK $\beta$ & AF031416 & $\begin{array}{l}\text { GCTTGAAGGCCAGAATCCAAC } \\
\text { GGCCCTCATTTAACTTGCC }\end{array}$ & 136 \\
\hline IR & M10051 & $\begin{array}{l}\text { CCAGTGATGTGTTTCCATGCTC } \\
\text { GCCTCACCCTTGATGATGTC }\end{array}$ & 146 \\
\hline $\mathrm{p} 85 \alpha$ & ВC094795 & $\begin{array}{l}\text { GATTGTGATACACCCTCCGTG } \\
\text { GCTGGAATGACAGGATTTGG }\end{array}$ & 104 \\
\hline $\mathrm{p} 85 \beta$ & ВС070082 & $\begin{array}{l}\text { GCAGGACCAGATTGTCAAGG } \\
\text { GCCTCAATTGCAGTACGCTTC }\end{array}$ & 163 \\
\hline $\mathrm{p} 110 \alpha$ & BC113601 & $\begin{array}{l}\text { GTACCTTGTTCCAATCCCAGG } \\
\text { GTTCCTCTTTAGCACCCTTTCG }\end{array}$ & 131 \\
\hline $\mathrm{p} 110 \beta$ & BC114432 & $\begin{array}{l}\text { GCTGGTTTGGATCTTCGGATG } \\
\text { CTTTGTTGAAGGCTGCTGCAG }\end{array}$ & 148 \\
\hline PTEN & ВС005821 & $\begin{array}{l}\text { GTTCAGTGGCGGAACTTG } \\
\text { GAACTTGTCTTCCCGTCGTG }\end{array}$ & 101 \\
\hline
\end{tabular}

$A k t 2 \mathrm{v}$-akt murine thymoma viral oncogene homologue $2, I K K \beta$ inhibitor- $\kappa \beta$ kinase- $\beta, I R$ insulin receptor, PI3K regulatory (p85 $\alpha$ and $\mathrm{p} 85 \beta)$ and catalytic (p110 $\alpha$ and $\mathrm{p} 110 \beta)$ subunits, PTEN phosphatase and tensin homolog
Proteins were detected using a 1:1000 dilution of anti-rabbit IgG conjugated to horseradish peroxidise (Sigma) in TTBS containing $1 \%(\mathrm{w} / \mathrm{v})$ skimmed milk powder for $45 \mathrm{~min}$ and then exposed to ECL-reagent for 1-2 min and developed. The molecular weight of the bands was estimated by comparison with pre-stained molecular weight markers (MW 10-250 kDa, Bio-Rad, Hemel Hempstead, UK) that were run in parallel with the samples. Bands were imaged using Image $\mathrm{J}$ software (National Institute of Health, Maryland, USA) and the results calculated as the ratio of phosphorylated to total protein relative to the BSA control, which is arbitrarily defined as $100 \%$.

\section{Statistical analysis}

Data were analysed using IBM SPSS statistics version 25. The fold changes in gene expression and ratios of phosphorylated to total protein were analysed using a mixed-factor ANOVA and results are presented in the text and figures as mean \pm SEM. The data were checked for normality and logtransformed where necessary to render their distribution normal before statistical analysis. When statistical differences were found in the ANOVA, a LSD posthoc test was applied to identify differences amongst the fatty acid treatments. Values of $P \leq 0.05$ were taken as significant.

\section{Results}

\section{OA has significant effects on the PI3K/Akt/eNOS pathway}

Fatty acid type $\mathrm{x}$ time interactions were observed for the mRNA expression of the insulin receptor $(P=0.001)$, p110 $\beta$ (a catalytic subunit of PI3K, $P=0.025$ ), p $85 \alpha$ (a regulatory subunit of PI3K, $P=0.011$ ) and eNOS $(P=0.001)$, with differences among the fatty acids only observed after the $24 \mathrm{~h}$ incubation (Fig. 1 and Table S1). Compared with PA and stearic acid (SA), OA downregulated the expression of the insulin receptor $(P \leq 0.017)$ whereas a greater expression was observed with SA than LA $(P=0.030)$. Similarly, OA down-regulated the expression of $\mathrm{p} 110 \beta$ compared with LA and SA $(P \leq 0.004)$, with a greater up-regulation with SA than LA $(P=0.003)$. OA also down-regulated the expression of $\mathrm{p} 85 \alpha$ compared with PA and LA $(P \leq 0.032)$ (Fig. 1A). A greater up-regulation of the expression of eNOS was observed with SA relative to the other fatty acids tested $(P<0.03)$ (Fig. 1B).

Significant effects of fatty acid type (data for the 3 and $24 \mathrm{~h}$ incubations combined) were observed on the mRNA expression of PTEN $(P<0.0001)$, IKK $\beta(P=0.023)$, Akt2 (v-akt murine thymoma viral oncogene homologue 


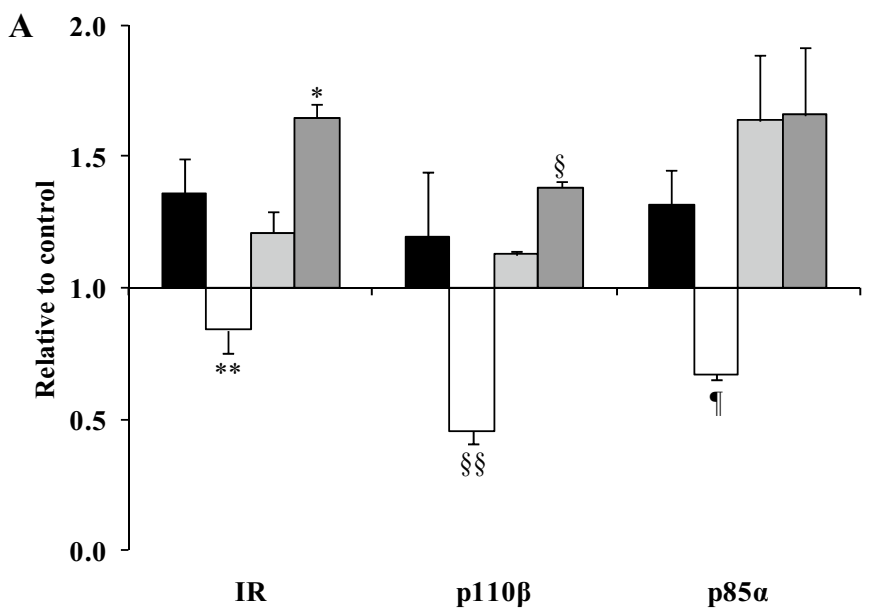

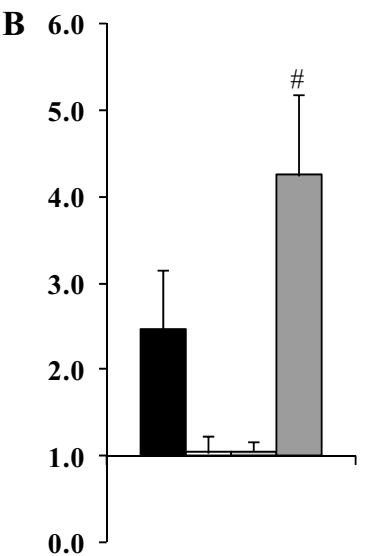

eNOS
Fig. 1 A OA down-regulates the expression of the insulin receptor (IR), regulatory (p110 $\beta$ ) and catalytic (p85 $\alpha$ ) subunits of PI3K whereas B SA up-regulates eNOS mRNA expression. HAEC cells were incubated with $100 \mu \mathrm{M}$ PA (black bars), OA (white bars), LA (grey bars) and SA (dark grey bars) for $24 \mathrm{~h}$. Data are presented as the fold change in mRNA expression (normalised for $\beta$-actin) relative to the BSA control (HAEC incubated with BSA equivalent to the amount present in the fatty acid-BSA complexes), which is arbitrarily

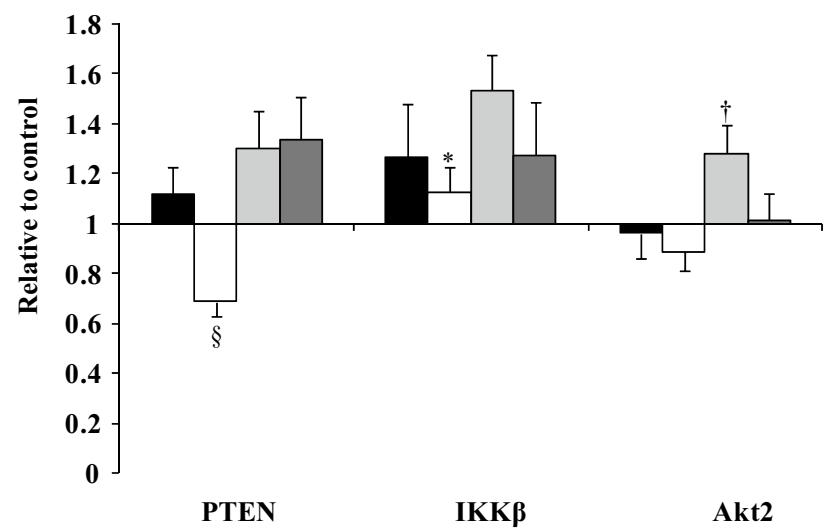

Fig. 2 Differential effects of $100 \mu \mathrm{M}$ PA (black bars), OA (white bars), LA (grey bars) and SA (dark grey bars) on the mRNA expression of PTEN, IKK $\beta$ and Akt 2 (data for the 3 and $24 \mathrm{~h}$ incubations combined). Each bar represents the fold change in mRNA (normalised for $\beta$-actin) relative to the BSA control, which is arbitrarily set as 1 . The real time RT-PCR was performed in duplicate, and values represent mean \pm SEM for three independent experiments. ${ }^{\S} P \leq 0.05$, relative to PTEN expression following PA, LA and SA; $* P=0.026$, relative to IKK $\beta$ expression following LA; ${ }^{\dagger} P<0.04$, relative to Akt2 expression following OA and SA

2) $(P=0.009)$ and VCAM-1 $(P=0.041)$. OA was shown to down-regulate the expression of PTEN compared with the PA, LA and SA $(P \leq 0.05)$. IKK $\beta$ gene expression was greater with LA than OA $(P=0.026)$, with a greater expression of Akt2 with LA compared with either OA $(P=0.015)$ or SA $(P=0.038)($ Fig. 2$)$. For VCAM-1, set as 1. The real time RT-PCR was performed in duplicate, and values represent mean \pm SEM for three independent experiments. Insulin receptor expression $* P=0.03$ relative to LA and $* * P<0.02$, relative to PA and SA. P110 $\beta$ gene expression ${ }^{\S} P=0.003$ relative to LA and ${ }^{\S \S} P \leq 0.004$ relative to LA and SA. P85 $\alpha$ expression ${ }^{\mathbb{T}} P \leq 0.032 \mathrm{com}-$ pared with LA and SA. eNOS gene expression ${ }^{\#} P<0.03$ relative to $\mathrm{PA}, \mathrm{OA}$ and LA

differences were not evident between PA, OA, SA and LA after post-hoc analysis.

In our cell signalling studies, there was a significant effect of fatty acid type on eNOS phosphorylation at $\operatorname{Ser}^{1177}$, calculated relative to the BSA control $(P=0.013)$ independent of whether the cells were stimulated with insulin or HBSS. Incubation of HAEC with $100 \mu \mathrm{M}$ OA was associated with greater eNOS phosphorylation at Ser $^{1177}$ than $100 \mu \mathrm{M}$ PA, SA and LA (ratios after stimulation with HBSS and insulin combined; $P \leq 0.047$ ) (Fig. 3). No significant effects were seen in the phosphorylation of Akt at $\mathrm{Ser}^{472}$ or $\mathrm{p} 42 / 44$ MAPK at $\mathrm{Thr}^{202 / 204}$ after the single fatty acid treatments, stimulated with HBSS or insulin (data not shown).

\section{Time-dependent effects of LC $n-3$ PUFA on vascular cell adhesion molecule- 1 expression}

Less marked effects were observed on the gene expression of proteins in the PI3K/Akt/eNOS pathway following incubation with $10 \mu \mathrm{M}$ EPA and DHA. A significant effect of fatty acid type was observed on VCAM-1 expression only $(P=0.05)$, with a tendency for a fatty acid type $\mathrm{x}$ time interaction $(P=0.08)$. At $3 \mathrm{~h}, \mathrm{VCAM}-1$ expression was significantly greater following incubation with EPA than DHA $(P=0.009)$, with a marked down-regulation in expression observed with both fatty acids at $24 \mathrm{~h}$ $(P \leq 0.001)$ (Fig. 4). 

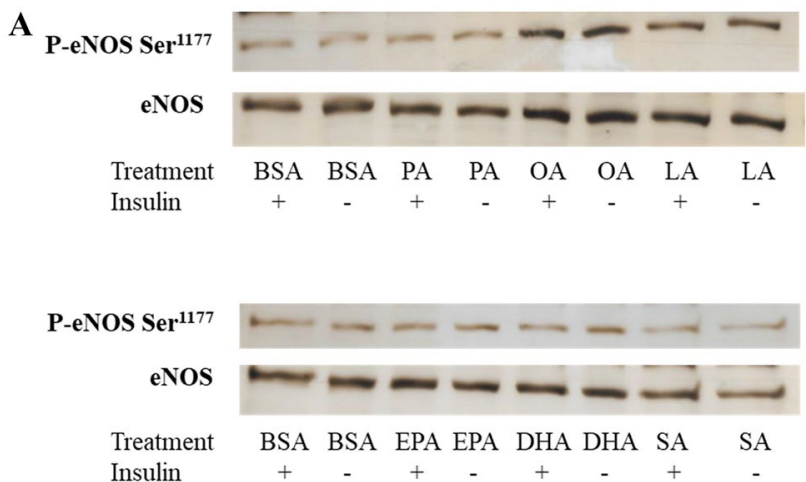

B

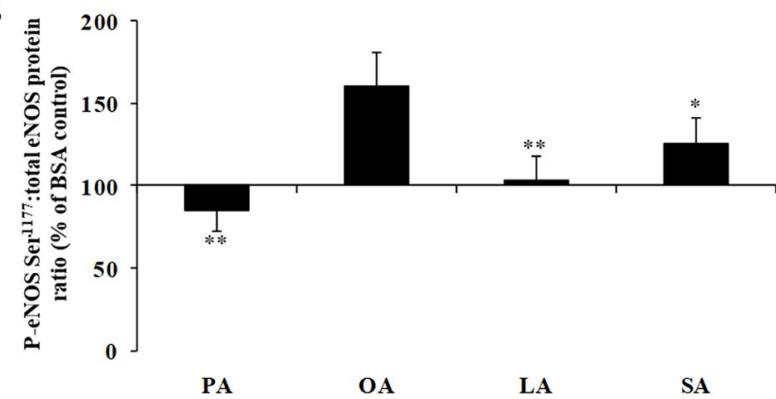

Fig. 3 A A typical Western blot analysis of phosphorylated eNOS Ser ${ }^{177}$ and total eNOS after incubation of HAEC cells with $100 \mu \mathrm{M}$ PA, OA, LA and SA, and $10 \mu \mathrm{M}$ EPA and DHA followed by stimulation with and without insulin $(1 \mu \mathrm{M})$ for $15 \mathrm{~min}$. B Greater eNOS phosphorylation at Ser ${ }^{1177}$ with OA. Each bar represents the phosphorylated:total eNOS protein ratio after incubation of HAEC with $100 \mu \mathrm{M}$ of PA, OA, SA and LA relative to the BSA control, which is arbitrarily set at $100 \%$. Data are pooled from several independent cell experiments $(n=10-12)$. $* * P \leq 0.009$ and $* P=0.047$, relative to $\mathrm{OA}$

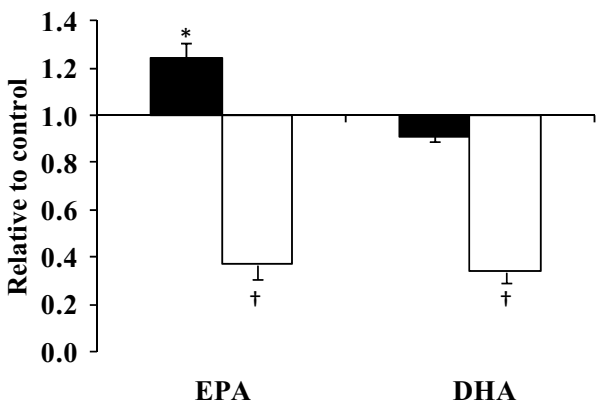

Fig. 4 Time-dependent effects of LC n-3 PUFA on VCAM-1 mRNA expression. HAEC were incubated for $3 \mathrm{~h}$ (black bars) and $24 \mathrm{~h}$ (white bars) with $10 \mu \mathrm{M}$ of EPA and DHA. Each bar represents the fold change in mRNA (normalised for $\beta$-actin) relative to the BSA control, which is arbitrarily set as 1 . The real time PCR was performed in duplicate, and values represent mean \pm SEM for three independent experiments. $* P=0.009$, compared with $3 \mathrm{~h}$ mRNA expression with DHA; ${ }^{\dagger} P \leq 0.001$, compared with the corresponding mRNA expression for the $3 \mathrm{~h}$ time point

\section{Both concentration and composition of the fatty acid mixtures influences expression of key proteins in the PI3K/Akt pathway}

The two fatty acid mixtures, SFA and SFA with LC n-3 PUFA, were incubated at two concentrations, $400 \mu \mathrm{M}$ and $800 \mu \mathrm{M}$, for a period of $3 \mathrm{~h}$. Although there were no significant fatty acid mixture $\times$ concentration interactions, to explore the effects of NEFA concentration representative of normal $(400 \mu \mathrm{M})$ and insulin resistant $(800 \mu \mathrm{M})$ states, the fold change in gene expression for the SFA and SFA with LC n-3 PUFA fatty acid mixtures were combined. Significant effects of concentration were observed on the mRNA expression of PTEN $(P=0.005)$, IKK $\beta(P=0.035)$, insulin receptor $(P=0.012)$, Akt2 $(P=0.008), \mathrm{p} 85 \alpha(P=0.021)$ and $\mathrm{p} 85 \beta(P=0.033)$, with each gene showing a greater down-regulation of mRNA expression with the $400 \mu \mathrm{M}$ than $800 \mu \mathrm{M}$ concentration (Fig. 5A).

To determine the overall impact of the fatty acid composition of the mixtures (SFA and SFA with LC n-3 PUFA), the fold change in gene expression for the $400 \mu \mathrm{M}$ and $800 \mu \mathrm{M}$ incubations were combined. Significant effects were only evident for the mRNA expression of PTEN $(P=0.009)$, $\operatorname{IKK} \beta(P=0.043)$, insulin receptor $(P=0.012)$, Akt2 $(P=0.006), \mathrm{p} 110 \beta(P=0.006)$ and $\mathrm{p} 85 \beta(P=0.002)$ between the mixtures. In general, the SFA with LC n-3 PUFA mixture led to a down-regulation of the gene expression relative to the SFA mixture apart from IKK $\beta$ where a greater down-regulation of expression was observed with the SFA mixture (Fig. 5B).

The cell signalling studies revealed no significant effect of the concentration or type of fatty acid mixture on phosphorylation of eNOS at $\mathrm{Ser}^{1177}$, Akt at $\mathrm{Ser}^{473}$ or p44/42 MAPK at $\mathrm{Thr}^{202} / \mathrm{Thr}^{204}$ (data not shown).

\section{Discussion}

Raised NEFA enriched in SFA are proposed to impair vascular function by attenuating insulin signalling via vasodilator pathways (PI3K/Akt/eNOS) and enhancing signalling via pro-inflammatory pathways (MAPK). However, very little is known about the effects of different fatty acid classes on these pathways in endothelial cells. In this in vitro study, we have reported that single fatty acids have differential effects on the expression of genes in the PI3K/Akt/eNOS pathway. Secondly, both the concentration and composition of the fatty acid mixtures, representative of circulating NEFA profiles from our previous human study, had significant influences on gene expression. 


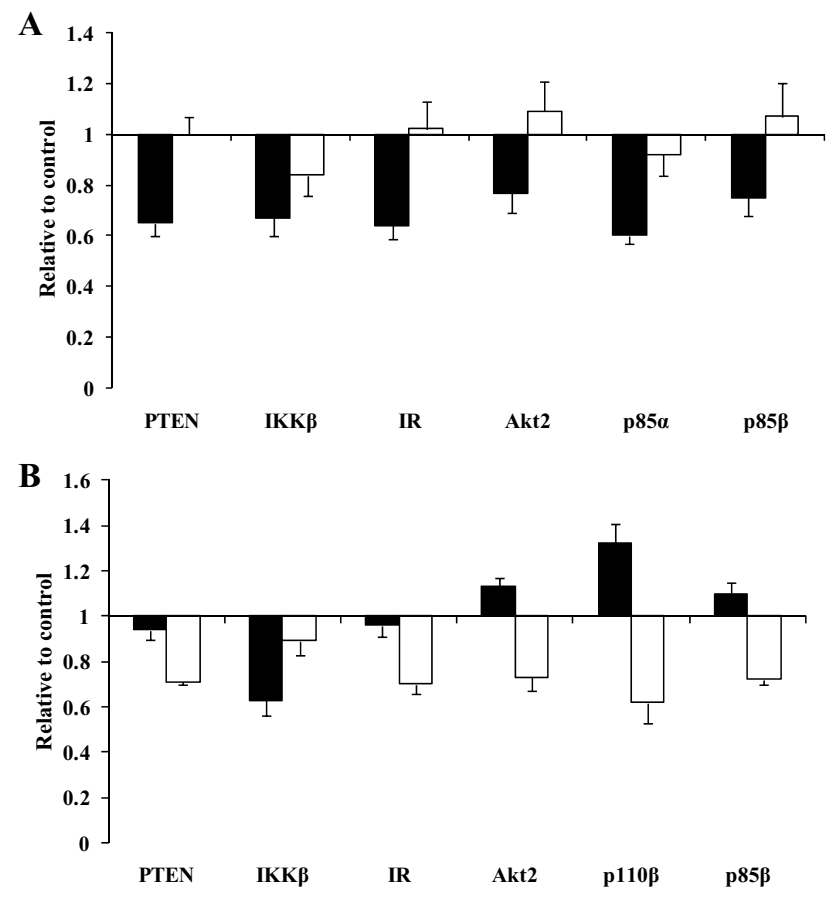

Fig. 5 Significant effects of A concentration (400 $\mu \mathrm{M}$ (black bars) versus $800 \mu \mathrm{M}$ (white bars)) and B composition [SFA (black bars) and SFA with LC n-3 PUFA (white bars)] of the fatty acid mixtures on the mRNA expression (normalised for $\beta$-actin) of key proteins in the PI3K/Akt signalling pathway. Each bar represents the fold change in mRNA relative to the BSA control, which is arbitrarily set as 1 . The real time RT-PCR was performed in duplicate, and values represent mean \pm SEM for three independent experiments. To determine the impact of fatty acid mixture concentration (A), gene expression data for the SFA and SFA with LC n-3 PUFA mixtures were combined whereas for fatty acid composition (B), data for the $400 \mu \mathrm{M}$ and $800 \mu \mathrm{M}$ incubations were combined

\section{Individual fatty acids}

Insulin mediates its effects by binding to insulin receptors and triggering the interaction between IRS- 1 and Class 1A PI3K, heterodimeric molecules consisting of a catalytic subunit (p110) and regulatory subunit (p85). This leads to the generation of phosphatidylinositol $(3,4,5)$-triphosphate $\left(\mathrm{PIP}_{3}\right)$ which acts as a second messenger activating Akt/protein kinase B, with Akt2 proposed to be the key downstream intermediate linked to insulin action in vascular endothelial cells [22, 23]. In general, OA down-regulated the expression of the insulin receptor, $\mathrm{p} 110 \beta$ and $\mathrm{p} 85 \alpha$ compared with PA, SA and LA, whereas SA increased expression of the insulin receptor and $\mathrm{p} 110 \beta$ relative to LA. As far as the authors are aware, this study is the first to determine the effects of fatty acids on the expression of both the catalytic ( $110 \alpha$ and $\beta$ ) and regulatory subunits (p85 and $\beta$ ) of the Class 1A PI3K, which are proposed to have opposing effects on insulin signalling [24]. Studies in knock-out mice suggest that the regulatory subunits may have negative effects on insulin action [25], with increased expression of p85 $\alpha$ also observed in mouse models of gestational diabetes [26] and in obese humans $[8,27]$. Conversely, reductions in $p 85 \alpha$ (and to a lesser extent $\mathrm{p} 85 \beta$ ) have been shown to enhance insulin sensitivity $[24,28]$ and lead to a decrease in the catalytic subunits $p 110 \alpha$ and $p 110 \beta$ in the insulin sensitive tissues of these knock-out animals [25]. Interestingly, our observations for OA of a decrease in $\mathrm{p} 85 \alpha$ and $\mathrm{p} 110 \beta$ expression suggest a co-ordinated down-regulation of these two subunits by OA and may indicate a direct effect of this fatty acid on PI3K. In agreement, opposing effects of $100 \mu \mathrm{M}$ OA and PA on the mRNA expression of $p 85 \alpha$ have been reported in visceral adipose tissue biopsies from morbidly obese individuals, albeit the reduction in $p 110 \beta$ expression was only evident at $25 \mu \mathrm{M}$ but not $100 \mu \mathrm{M}$ OA in this cell type [8]. Differences in the responsiveness of $\mathrm{p} 110 \beta$ to the actions of OA between studies may reflect the cell types used (endothelial cells versus visceral adipose tissue) and the phenotype of the adipose tissue donors (obese participants). Evidence from cancer cell lines have indicated that OA may activate PI3K by binding to the G protein-coupled receptors (GPCR, such as GPCR40 and 120), leading to transactivation of epidermal growth factor receptors via Src, activating a wide variety of pathways including PI3K/Akt [29, 30]. Although PI3K have been shown to be activated by tyrosine kinases, such as the insulin receptor, and by GPCR, the latter pathway has been shown to be inactivated by SFA [31]. Therefore, it is possible that OA may be influencing the expression of the PI3K subunits by binding to certain GPCR.

In addition to its well established effects on PI3K activation, it has been proposed that the regulatory subunit $\mathrm{p} 85 \alpha$ forms part of a complex feedback regulatory system which modulates insulin signalling by activating PTEN [32, 33], one of the lipid phosphatases reported to antagonise the PI3K/Akt pathway by dephosphorylating $\mathrm{PIP}_{3}$ [34]. In vitro studies have previously reported fatty acid effects on PTEN expression in a number of different cell types [5, 35-37]. Up-regulation of expression was observed in endothelial cells after incubation with $200-800 \mu \mathrm{M}$ PA [5] and in a breast cancer cell line with $50 \mathrm{ng} / \mathrm{ml}$ (approximately $15 \mu \mathrm{M}$ ) of EPA and DHA [35], whereas $50 \mu \mathrm{M}$ [36] and $500 \mu \mathrm{M}$ [37] of OA down-regulated PTEN in HepG 2 cells. In agreement with this literature, we also observed a down-regulation of PTEN in HAEC with OA at $100 \mu \mathrm{M}$, with an up-regulation of mRNA expression with both SFA (PA and SA) and LA. The co-ordinated downregulation of $\mathrm{p} 85 \alpha, \mathrm{p} 110 \beta$ and PTEN with OA suggests a promotion of signalling via PI3K/Akt, and this finding is supported by the greater eNOS phosphorylation at Ser ${ }^{1177}$ found with OA relative to PA, LA and SA. Improvements in insulin sensitivity with MUFA-rich diets have previously been observed, but findings have been inconsistent in both healthy and insulin resistant adults [38-40], with 
evidence to suggest that MUFA-rich diets or test meals may also lead to impaired vascular reactivity. However, insulin stimulation of the cells after fatty acid treatment did not reveal any further differences in phosphorylation at eNOS at $\mathrm{Ser}^{1177}$ or Akt at $\mathrm{Ser}^{473}$, but this may reflect the dose of insulin $(1 \mu \mathrm{M})$ used in the cell experiments, which is known to stimulate insulin-like growth factor 1 receptor in addition to the insulin receptor [41].

In the present study, differences in the expression of the insulin receptor were also observed after $24 \mathrm{~h}$, with a lower expression with OA relative to PA and SA. Our findings are in contrast with previous observations which have shown a decrease in expression and post-receptor signalling with a range of PA concentrations $(250-750 \mu \mathrm{M})$ in different cell types [42-44]. However, the effects of unsaturated fatty acids were not included in these previous studies. Our observations of an up-regulation in expression after $24 \mathrm{~h}$ with SFA, relative to OA, may be explained by the type of cells used in this in vitro study (hepatocytes are a more anabolic tissue than endothelial cells), or the lower concentration of fatty acids treatments $(100 \mu \mathrm{M})$, and/or the level of signalling via the PI3K/Akt pathway. The marked effect of OA on the PI3K/Akt/eNOS pathway is intriguing and further work is warranted to determine the primary site of regulation of this pathway by OA. Potential candidates could include the insulin receptor, PI3K regulatory subunits, PTEN or certain GPCR.

It has been demonstrated that IKK $\beta$, the serine kinase which regulates the activation of $\mathrm{NFKB}$, also uses IRS- 1 as a substrate for serine phosphorylation, with activation of IKK $\beta$ providing a key pathway for the attenuation of insulin signalling via PI3K/Akt [13]. Although a greater IKK $\beta$ mRNA expression was observed with LA than OA, the induction of gene expression for the cell adhesion molecule VCAM-1 by $\mathrm{NF \kappa B}$ was not evident after incubation with PA, SA, LA and $\mathrm{OA}$, with differential effects on expression only observed with the LC n-3 PUFA. Acute exposure of the cells caused an up-regulation of VCAM-1 mRNA expression with EPA compared with DHA, whereas the chronic $24 \mathrm{~h}$ exposure down-regulated expression to the same extent following both fatty acids. These time dependent effects of LC n-3 PUFA on VCAM-1 expression have previously been observed in our group using human umbilical vein endothelial cells [11] highlighting the importance of length of fatty acid exposure on gene expression and cell signalling, since changes in membrane composition may occur during the longer incubations. Increased eNOS levels have been associated with reduced inflammation via the effects of the vasodilator nitric oxide on VCAM-1 expression [45]. Compared with the control, incubation with SA produced a 4.5 -fold greater eNOS mRNA expression compared with PA ( 2.5 fold) and unsaturated fatty acids ( 1.1 fold) which was mirrored in the VCAM-1 expression, although the differences between fatty acids were not significant. As suggested previously, a negative feedback may exist in which cells up-regulate eNOS expression to reverse the inflammatory effects mediated by the fatty acid exposures [11].

\section{Fatty acid mixtures-effects of concentration and composition}

Elevated NEFA concentrations are characteristic of conditions such as obesity and type II diabetes. Incubation with the fatty acid mixtures at 400 and $800 \mu \mathrm{M}$ revealed differential effects on the expression of the insulin receptor, regulatory subunits of PI3K (p85 $\alpha$ and $\beta$ ), IKK $\beta$ and Akt2, with a consistent down-regulation of expression with $400 \mu \mathrm{M}$ compared with $800 \mu \mathrm{M}$. A greater down-regulation of $\mathrm{p} 85 \alpha, \mathrm{p} 85 \beta$, PTEN and IKK $\beta$ is generally consistent with the possibility that the $400 \mu \mathrm{M}$ concentration (typical fasting level for humans) is likely to be associated with greater insulin sensitivity than with the $800 \mu \mathrm{M}$ concentration (levels observed in diabetes or after a very high fat meal). However, the reduction in Akt2 expression conflicts with this interpretation since Akt knock-out animals exhibit a diabetic phenotype consistent with insulin resistance [46]. It is possible that the reduction in expression with $400 \mu \mathrm{M}$ may reflect an adaptive response to the down-regulation of the PI3K subunits and PTEN, which are upstream of Akt, or alternatively a compensatory effect associated with changes in other Akt isoforms present in the endothelial cells.

We have previously shown experimental elevation of NEFA enriched in SFA with LC n-3 PUFA to reverse the detrimental effects of SFA on flow mediated dilatation in healthy adults [3]. Incubation with a fatty acid mixture representative of the plasma NEFA fatty acid composition after the SFA with LC n-3 PUFA test drinks led to a down-regulation of the insulin receptor, p110 $\beta$, p85 $\beta$, PTEN and Akt compared with the SFA mixture, with a greater down-regulation of IKK $\beta$ with the SFA mixture. The downregulation of PI3K subunits and PTEN suggests greater signalling via the PI3K/Akt pathway with the SFA and LC n-3 PUFA mixture which may have contributed to the improved vascular function. However, in our cell signalling studies, differences were not observed in the phosphorylation status of eNOS at $\operatorname{Ser}^{1177}$ or Akt at $\operatorname{Ser}^{473}$ between the fatty acid mixtures. Therefore, it is possible that other pathways or mechanisms may have played a more significant role in mediating the beneficial effects of LC n-3 PUFA on vascular function in our human study, such as direct effects of the fatty acids on the smooth muscle cell layer and bioavailability of nitric oxide [47].

A strength of this in vitro study is the use of concentrations reflective of circulating individual fatty acids and the comparison with fatty acid mixtures representative of postprandial plasma NEFA after meal ingestion. Our findings highlight the 
differences in the magnitude of the effects of the fatty acids on mRNA gene expression when they are incubated with the cells alone versus in combination with other dietary fatty acids. We have previously observed a similar phenomenon on the expression of genes involved in endothelial activation following incubation with single dairy fatty acids and mixtures representative of low and high dairy intakes [48]. This highlights the need for careful interpretation of findings from in vitro and ex-vivo studies using single fatty acids. However, this study also has some limitations. We used a primary endothelial cell line to determine the mechanisms of action of fatty acids on the expression of genes involved in the PI3K/Akt pathway and eNOS phosphorylation which does not represent the in vivo situation in which cells lining the blood vessel wall are in close contact with the underlying smooth muscle layer. Our study also focussed specifically on key genes involved in the PI3K/ Akt pathway and so we cannot discount that other genes or proteins involved in this pathway may have been mediating the effects observed. Furthermore, cell medium nitric oxide concentrations and HAEC membrane FA compositions were not measured following the acute and chronic incubations in which to relate to the eNOS phosphorylation data and gene expression data. Studies are needed which examine the insulin signalling pathways in the endothelium in greater detail.

\section{Conclusion}

We report for the first time the effects of OA on the mRNA expression of the regulatory (p85 $\alpha)$ and catalytic (p110 $\beta$ ) subunits of PI3K in endothelial cells, in addition to confirming previous observations of this fatty acid on $\mathrm{p} 85 \alpha[8]$ and PTEN expression [36]. These findings may, in the case of some of the reported effects, appear counter intuitive or contrary to what may have been predicted. However, together with the cell signalling studies, our data suggests effects of OA on the expression of the PI3K/Akt/eNOS pathway are consistent with improved insulin sensitivity observed in knock-out animal studies, where down-regulation of the PI3K regulatory subunits appear to be inversely correlated with insulin sensitivity. Furthermore, our findings also contribute to a better understanding of how both the concentration and composition of fatty acid mixtures may influence endothelial function by modulation of the PI3K/Akt pathway. In view of the increasing prevalence of the metabolic syndrome and type II diabetes in the population, further work is required to determine the underlying molecular basis of insulin resistance in the endothelium and the modulatory effects of dietary lipids.

Supplementary Information The online version contains supplementary material available at https://doi.org/10.1007/s00394-022-02821-2.
Acknowledgements The authors would like to thank Dr Ian Salt at the University of Glasgow for advice on the culturing conditions of the human aortic endothelial cells for the insulin signalling studies, and Professor Parveen Yaqoob (University of Reading) and Dr David Vazour (University of East Anglia) for providing help and advice during the method development of the insulin signalling studies.

Author contributions Conceptualization, KGJ, KJN, AKT and CMW; methodology development, execution of cell culture studies and Western Blot Analysis, KJN, KGJ and MJF; RNA extraction, cDNA synthesis and gene expression studies KGJ; data analysis and interpretation KGJ, KJN and CMW; writing - original draft preparation, KGJ; writing-review and editing, CMW, KJN, AKT and KGJ; funding acquisition, CMW, MJF and KGJ. All authors have read and agreed to the published version of the manuscript.

Funding This work was supported by the Biotechnology and Biological Sciences Research Council (BB/E0221816/1) and Unilever Discover.

Data availability statement All data generated or analysed during this study are included in this published article and its associated Supplementary Materials files. The data that support the findings of this study are available from the corresponding author upon reasonable request.

\section{Declarations}

Conflict of interest The authors declare no conflict of interest. The funders had no role in the design of the study; in the collection, analyses, or interpretation of data; in the writing of the manuscript, or in the decision to publish the results.

Informed consent statement Not applicable.

Open Access This article is licensed under a Creative Commons Attribution 4.0 International License, which permits use, sharing, adaptation, distribution and reproduction in any medium or format, as long as you give appropriate credit to the original author(s) and the source, provide a link to the Creative Commons licence, and indicate if changes were made. The images or other third party material in this article are included in the article's Creative Commons licence, unless indicated otherwise in a credit line to the material. If material is not included in the article's Creative Commons licence and your intended use is not permitted by statutory regulation or exceeds the permitted use, you will need to obtain permission directly from the copyright holder. To view a copy of this licence, visit http://creativecommons.org/licenses/by/4.0/.

\section{References}

1. Lind L, Fugmann A, Branth S, Vessby B, Millgard J, Berne C, Lithell $\mathrm{H}$ (2000) The impairment in endothelial function induced by non-esterified fatty acids can be reversed by insulin. Clin Sci 99(3):169-174. https://doi.org/10.1042/cs19990367

2. Li H, Li H, Bao Y, Zhang X, Yu Y (2011) Free fatty acids induce endothelial dysfunction and activate protein kinase $\mathrm{C}$ and nuclear factor-kappa B pathway in rat aorta. Int J Cardiol 152(2):218-224. https://doi.org/10.1016/j.ijcard.2010.07.019

3. Newens KJ, Thompson AK, Jackson KG, Wright J, Williams CM (2011) DHA-rich fish oil reverses the detrimental effects of 
saturated fatty acids on postprandial vascular reactivity. Am J Clin Nutr 94(3):742-748. https://doi.org/10.3945/ajen.110.009233

4. Kim F, Tysseling KA, Rice J, Pham M, Haji L, Gallis BM, Baas AS, Paramsothy P, Giachelli CM, Corson MA, Raines EW (2005) Free fatty acid impairment of nitric oxide production in endothelial cells is mediated by IKK beta. Arterioscler Thromb Vasc Biol 25(5):989-994. https://doi.org/10.1161/01.ATV.0000160549. 60980.a8

5. Wang XL, Zhang L, Youker K, Zhang M-X, Wang J, LeMaire SA, Coselli JS, Shen YH (2006) Free fatty acids inhibit insulin signaling-stimulated endothelial nitric oxide synthase activation through upregulating PTEN or inhibiting Akt kinase. Diabetes 55(8):2301-2310. https://doi.org/10.2337/db05-1574

6. Xiao-Yun X, Zhuo-Xiong C, Min-Xiang L, Xingxuan H, Schuchman EH, Feng L, Han-Song X, An-Hua L (2009) Ceramide mediates inhibition of the AKT/eNOS signaling pathway by palmitate in human vascular endothelial cells. Med Sci Monit 15(9):BR254-261

7. Zhao W, Wu C, Li S, Chen X (2016) Adiponectin protects palmitic acid induced endothelial inflammation and insulin resistance via regulating ROS/IKK $\beta$ pathways. Cytokine 88:167-176. https://doi.org/10.1016/j.cyto.2016.09.005

8. López-Gómez C, Santiago-Fernández C, García-Serrano S, García-Escobar E, Gutiérrez-Repiso C, Rodríguez-Díaz C, Ho-Plágaro A, Martín-Reyes F, Garrido-Sánchez L, Valdés S, Rodríguez-Cañete A, Rodríguez-Pacheco F, García-Fuentes E (2020) Oleic acid protects against insulin resistance by regulating the genes related to the PI3K signaling pathway. J Clin Med. https://doi.org/10.3390/jcm9082615

9. Collie-Duguid ESR, Wahle KWJ (1996) Inhibitory effect of fish oil N-3 polyunsaturated fatty acids on the expression of endothelial cell adhesion molecules. Biochem Biophys Res Commun 220(3):969-974. https://doi.org/10.1006/bbrc.1996. 0516

10. Dichtl W, Ares MPS, Jonson AN, Jovinge S, Pachinger O, Giachelli CM, Hamsten A, Eriksson P, Nilsson J (2002) Linoleic acid-stimulated vascular adhesion molecule- 1 expression in endothelial cells depends on nuclear factor-kappa B activation. Metab Clin Exp 51(3):327-333. https://doi.org/10.1053/meta. 2002.29963

11. Shaw DI, Hall WL, Jeffs NR, Williams CM (2007) Comparative effects of fatty acids on endothelial inflammatory gene expression. Eur J Nutr 46(6):321-328. https://doi.org/10.1007/ s00394-007-0669-4

12. Shi X, Wang S, Luan H, Tuerhong D, Lin Y, Liang J, Xiong Y, Rui L, Wu F (2019) Clinopodium chinense attenuates palmitic acidinduced vascular endothelial inflammation and insulin resistance through TLR4-mediated NF- $\mathrm{B}$ and MAPK pathways. Am J Chin Med 47(1):97-117. https://doi.org/10.1142/s0192415x19500058

13. Gao ZG, Hwang D, Bataille F, Lefevre M, York D, Quon M, Ye JP (2002) Serine phosphorylation of insulin receptor substrate 1 by inhibitor kappa B kinase complex. J Biol Chem 277(50):4811548121. https://doi.org/10.1074/jbc.M209459200

14. Palomer X, Pizarro-Delgado J, Barroso E, Vázquez-Carrera M (2018) Palmitic and oleic acid: the yin and yang of fatty acids in type 2 diabetes mellitus. Trends Endocrinol Metab 29(3):178190. https://doi.org/10.1016/j.tem.2017.11.009

15. Ritchie SA, Kohlhaas CF, Boyd AR, Yalla KC, Walsh K, Connell JMC, Salt IP (2010) Insulin-stimulated phosphorylation of endothelial nitric oxide synthase at serine- 615 contributes to nitric oxide synthesis. Biochem J 426:85-90. https://doi.org/10.1042/ bj20091580

16. Newens KJ, Thompson AK, Jackson KG, Wright J, Williams CM (2010) Acute effects of elevated NEFA on vascular function: a comparison of SFA and MUFA. Br J Nutr 105(9):1343-1351. https://doi.org/10.1017/s0007114510004976
17. Miles JM, Wooldridge D, Grellner WJ, Windsor S, Isley WL, Klein S, Harris WS (2003) Nocturnal and postprandial free fatty acid kinetics in normal and type 2 diabetic subjects-effects of insulin sensitization therapy. Diabetes 52(3):675-681. https://doi. org/10.2337/diabetes.52.3.675

18. Karpe F, Dickmann JR, Frayn KN (2011) Fatty acids, obesity, and insulin resistance: time for a reevaluation. Diabetes 60(10):24412449. https://doi.org/10.2337/db11-0425

19. Bateman PA, Jackson KG, Maitin V, Yaqoob P, Williams CA (2007) Differences in cell morphology, lipid and apo B secretory capacity in caco- 2 cells following long term treatment with saturated and monounsaturated fatty acids. BBA Mol Cell Biol L 1771(4):475-485. https://doi.org/10.1016/j.bbalip.2007.02.001

20. Miyamoto Y, Saito Y, Kajiyama N, Yoshimura M, Shimasaki Y, Nakayama M, Kamitani S, Harada M, Ishikawa M, Kuwahara K, Ogawa E, Hamanaka I, Takahashi N, Kaneshige T, Teraoka H, Akamizu T, Azuma N, Yoshimasa Y, Yoshimasa T, Itoh H, Masuda I, Yasue H, Nakao K (1998) Endothelial nitric oxide synthase gene is positively associated with essential hypertension. Hypertension 32(1):3-8

21. Vafeiadou K, Vauzour D, Lee HY, Rodriguez-Mateos A, Williams RJ, Spencer JPE (2009) The citrus flavanone naringenin inhibits inflammatory signalling in glial cells and protects against neuroinflammatory injury. Arch Biochem Biophys 484(1):100-109. https://doi.org/10.1016/j.abb.2009.01.016

22. Rask-Madsen C, Li Q, Freund B, Feather D, Abramov R, Wu IH, Chen K, Yamamoto-Hiraoka J, Goldenbogen J, Sotiropoulos KB, Clermont A, Geraldes P, Dall'Osso C, Wagers AJ, Huang PL, Rekhter M, Scalia R, Kahn CR, King GL (2010) Loss of insulin signaling in vascular endothelial cells accelerates atherosclerosis in apolipoprotein E null mice. Cell Metab 11(5):379-389. https:// doi.org/10.1016/j.cmet.2010.03.013

23. King GL, Park K, Li Q (2016) Selective insulin resistance and the development of cardiovascular diseases in Diabetes: the 2015 Edwin Bierman Award Lecture. Diabetes 65(6):1462-1471. https://doi.org/10.2337/db16-0152

24. Ueki K, Fruman DA, Yballe CM, Fasshauer M, Klein J, Asano T, Cantley LC, Kahn CR (2003) Positive and negative roles of p85 alpha and p85 beta regulatory subunits of phosphoinositide 3-kinase in insulin signaling. J Biol Chem 278(48):48453-48466. https://doi.org/10.1074/jbc.M305602200

25. Brachmann SM, Ueki K, Engelman JA, Kahn RC, Cantley LC (2005) Phosphoinositide 3-kinase catalytic subunit deletion and regulatory subunit deletion have opposite effects on insulin sensitivity in mice. Mol Cell Biol 25(5):1596-1607. https://doi.org/ 10.1128/mcb.25.5.1596-1607.2005

26. Barbour LA, Shao JH, Qiao LP, Leitner W, Anderson M, Friedman JE, Draznin B (2004) Human placental growth hormone increases expression of the $\mathrm{p} 85$ regulatory unit of phosphatidylinositol 3-kinase and triggers severe insulin resistance in skeletal muscle. Endocrinology 145(3):1144-1150. https://doi.org/10. 1210/en.2003-1297

27. Bandyopadhyay GK, Yu JG, Ofrecio J, Olefsky JM (2005) Increased p85/55/50 expression and decreased phosphotidylinositol 3-kinase activity in insulin-resistant human skeletal muscle. Diabetes 54(8):2351-2359. https://doi.org/10.2337/diabetes.54.8. 2351

28. Mauvais-Jarvis F, Ueki K, Fruman DA, Hirshman MF, Sakamoto K, Goodyear LJ, Iannacone M, Accili D, Cantley LC, Kahn CR (2002) Reduced expression of the murine p85 alpha subunit of phosphoinositide 3-kinase improves insulin signaling and ameliorates diabetes. J Clin Investig 109(1):141-149. https://doi.org/ 10.1172/jci13305

29. Hardy S, St-Onge GG, Joly E, Langelier Y, Prentki M (2005) Oleate promotes the proliferation of breast cancer cells via the $\mathrm{G}$ 
protein-coupled receptor GPR40. J Biol Chem 280(14):1328513291. https://doi.org/10.1074/jbc.M410922200

30. Hirasawa A, Tsumaya K, Awaji T, Katsuma S, Adachi T, Yamada M, Sugimoto Y, Miyazaki S, Tsujimoto G (2005) Free fatty acids regulate gut incretin glucagon-like peptide-1 secretion through GPR120. Nat Med 11(1):90-94. https://doi.org/10.1038/nm1168

31. Meng Y, Yuan C, Zhang J, Zhang F, Fu Q, Zhu X, Shu G, Wang L, Gao P, Xi Q, Sun J, Zhang Y, Jiang Q, Wang S (2017) Stearic acid suppresses mammary gland development by inhibiting PI3K/Akt signaling pathway through GPR120 in pubertal mice. Biochem Biophys Res Commun 491(1):192-197. https://doi.org/10.1016/j. bbrc.2017.07.075

32. Taniguchi CM, Tran TT, Kondo T, Luo J, Ueki K, Cantley LC, Kahn CR (2006) Phosphoinositide 3-kinase regulatory subunit p85 alpha suppresses insulin action via positive regulation of PTEN. Proc Natl Acad Sci USA 103(32):12093-12097. https:// doi.org/10.1073/pnas.0604628103

33. Rabinovsky R, Pochanard P, McNear C, Brachmann SM, DukeCohan JS, Garraway LA, Sellers WR (2009) p85 Associates with Unphosphorylated PTEN and the PTEN-Associated Complex. Mol Cell Biol 29(19):5377-5388. https://doi.org/10.1128/mcb. 01649-08

34. Downes CP, Perera N, Ross S, Leslie NR (2007) Substrate specificity and acute regulation of the tumour suppressor phosphatase. PTEN Biochem Soc Symp 74:69-80

35. Ghosh-Choudhury T, Mandal CC, Woodruff K, St Clair P, Fernandes G, Choudhury GG, Ghosh-Choudhury N (2009) Fish oil targets PTEN to regulate NF kappa B for downregulation of antiapoptotic genes in breast tumor growth. Breast Cancer Res Treat 118(1):213-228. https://doi.org/10.1007/s10549-008-0227-7

36. Vinciguerra M, Sgroi A, Veyrat-Durebex C, Rubbia-Brandt L, Buhler LH, Foti M (2009) Unsaturated fatty acids inhibit the expression of tumor suppressor Phosphatase and Tensin Homolog (PTEN) via MicroRNA-21 up-regulation in hepatocytes. Hepatology 49(4):1176-1184. https://doi.org/10.1002/hep.22737

37. Wu HT, Chen W, Cheng KC, Ku PM, Yeh CH, Cheng JT (2012) Oleic acid activates peroxisome proliferator-activated receptor $\delta$ to compensate insulin resistance in steatotic cells. J Nutr Biochem 23(10):1264-1270. https://doi.org/10.1016/j.jnutbio.2011.07.006

38. Jackson KG, Lovegrove JA (2010) The role of monounsaturated fatty acids in insulin resistance mitigation. Curr Cardiovasc Risk Rep 4:390-397

39. Julibert A, Bibiloni MDM, Bouzas C, Martínez-González M, Salas-Salvadó J, Corella D, Zomeño MD, Romaguera D, Vioque J, Alonso-Gómez ÁM, Wärnberg J, Martínez JA, Serra-Majem L, Estruch R, Tinahones FJ, Lapetra J, Pintó X, Lopez-Miranda J, García-Molina L, Gaforio JJ, Matía-Martín P, Daimiel L, MartínSánchez V, Vidal J, Vázquez C, Ros E, Toledo E, Becerra-Tomás N, Pórtoles O, Pérez-Vega KA, Fiol M, Torres-Collado L, TojalSierra L, Carabaño-Moral R, Abete I, Sanchez-Villegas A, Casas
R, Bernal-López MR, Santos-Lozano JM, Galera A, Ugarriza L, Ruiz-Canela M, Babio N, Coltell O, Schröder H, Konieczna J, Orozco-Beltrán D, Sorto-Sánchez C, Eguaras S, Barrubés L, Fitó M, Tur JA (2019) Total and subtypes of dietary fat intake and its association with components of the metabolic syndrome in a mediterranean population at high cardiovascular risk. Nutrients. https://doi.org/10.3390/nu11071493

40. Imamura F, Micha R, Wu JH, de Otto MCO, Otite FO, Abioye AI, Mozaffarian D (2016) Effects of saturated fat, polyunsaturated fat, monounsaturated fat, and carbohydrate on glucose-insulin homeostasis: a systematic review and meta-analysis of randomised controlled feeding trials. PLoS Med 13(7):e1002087. https://doi.org/ 10.1371/journal.pmed.1002087

41. Zeng GY, Quon MJ (1996) Insulin-stimulated production of nitric oxide is inhibited by wortmannin - direct measurement in vascular endothelial cells. J Clin Investig 98(4):894-898. https://doi. org/10.1172/jci118871

42. Ruddock MW, Stein A, Landaker E, Park J, Cooksey RC, McClain D, Patti M-E (2008) Saturated fatty acids inhibit hepatic insulin action by modulating insulin receptor expression and postreceptor signalling. J Biochem 144(5):599-607. https://doi.org/ 10.1093/jb/mvn 105

43. Piro S, Maniscalchi ET, Monello A, Pandini G, Mascali LG, Rabuazzo AM, Purrello F (2010) Palmitate affects insulin receptor phosphorylation and intracellular insulin signal in a pancreatic alpha-cell line. Endocrinology 151(9):4197-4206. https://doi.org/ 10.1210/en.2009-1472

44. Dey D, Mukherjee M, Basu D, Datta M, Roy SS, Bandyopadhyay A, Bhattacharya S (2005) Inhibition of insulin receptor gene expression and insulin signaling by fatty acid: interplay of PKC isoforms therein. Cell Physiol Biochem 16(4-6):217-228. https:// doi.org/10.1159/000089847

45. Khan BV, Harrison DG, Olbrych MT, Alexander RW, Medford RM (1996) Nitric oxide regulates vascular cell adhesion molecule 1 gene expression and redox-sensitive transcriptional events in human vascular endothelial cells. Proc Natl Acad Sci USA 93(17):9114-9119. https://doi.org/10.1073/pnas.93.17.9114

46. Xu PZ, Chen ML, Jeon SM, Peng XD, Hay N (2012) The effect Akt 2 deletion on tumor development in Pten(+/-) mice. Oncogene 31(4):518-526. https://doi.org/10.1038/onc.2011.243

47. Armah CK, Jackson KG, Doman I, James L, Cheghani F, Minihane AM (2008) Fish oil fatty acids improve postprandial vascular reactivity in healthy men. Clin Sci 114(11-12):679-686. https:// doi.org/10.1042/cs20070277

48. Livingstone KM, Givens DI, Jackson KG, Lovegrove JA (2014) Comparative effect of dairy fatty acids on cell adhesion molecules, nitric oxide and relative gene expression in healthy and diabetic human aortic endothelial cells. Atherosclerosis 234(1):65-72. https://doi.org/10.1016/j.atherosclerosis.2014.02.015 